\title{
Implementation of Online Prostitution Crime Investigation in Polres Cirebon City Jurisdictions
}

\author{
Arif Zaenal Abidin ${ }^{1}$
}

Abstract. Online prostitution is prostitution or activities that make a person as an object to be traded through electronic or online media, the media used, such as Whatsapp and other applications. In other words, here the people those who are responsible to be able to respect the norms and values embodied in the lives of people for cases of online prostitution can destroy the future of the nation in case they were found with offenders who are still teenagers and the lack of regulation of traction. Regulations invitation to entrap prostitutes. In this research, the author uses socio-juridical namely the review of secondary data in the form of legislation, as well as the outcome of legal scholars, such as books related to the subject matter to then proceed with research on primary data (obtained directly from the respondents). From the research problem, there are two things that can be inferred. Law enforcement against criminal acts of online prostitution in Polres Cirebon City Jurisdictions has been running and has conducted a series of investigative actions and investigations to unravel the cases of online prostitution. From the results of investigations conducted by the Police Cirebon Resort know that the perpetrators of online prostitution utilize Whatsapp. Building partnerships with the wider community partnerships in the wider community to help hack into your account - an account associated with seller of "young women" through online media. Suggestions in this research are; The first law enforcement against criminal acts of online prostitution by Polres Cirebon should be more intensive and thorough, because online prostitution is spreading very fast and the activities or transactions done through electronic media that police had difficulty in finding evidence and the investigation process difficult. Secondly, the hope that more people concerned about this online prostitution activities to facilitate the Polres Cirebon in overcoming it.

Keywords: Law Enforcement; Criminal Act; Online Prostitution.

\section{Introduction}

The origin of prostitution in Indonesia can be traced back to the past - the kingdom of Java, where the trafficking of women at the time were fixtures of the feudal system of government. At that time, the concept of the power of a king is portrayed as a power great and noble nature. They are often regarded as someone who is in power not only property, but also their bondsmen. ${ }^{2}$ Prostitution is also evolving with the times, the era of Information and Communication Technology (ICT) also affect protitusi itself. Information and communication technologies have become a part of life that can not be separated. Even for some oarng ICT has become a major bagioin implementation of activities. Like the real world, in the world of ICT in addition to things "good things are so many things" bad things lurk. ${ }^{3}$ Online prostitution is prostitution activity or an activity that makes a person as

\footnotetext{
${ }^{1}$ Student of Master of Law, Universitas Islam Sultan Agung Semarang and Police Members Officer Email: arif.reaz808@gmail.com

${ }^{2}$ Terence H. Hull Endang Sulistyaningsih dan Gavin W 1997 Pelacuran di Indonesia Sejarah dan Perkembangannya Pustaka Sinar Harapan Jakarta p.1.

${ }^{3}$ Cahyana Ahmadjayadi "Cybercrime Dan Cyberporn Dikaitkan Dengan RUU Informasi Dan Transaksi Elektronik" conveyed to the seminar by BPHN Depatermen law and HAM July 6th 2007.
} 
an object for traded via electronic or online media, media that is in use as, Whatsapp, and other applications. Online prostitution conducted by the media because it easier, cheaper, more practical and safer than the raid officers of the prostitution that is done in the conventional manner. ${ }^{4}$ According to Bonger prostitution is social phenomenon where women sell themselves "sexual acts" as a livelihood. This definition is clearly stated on the sales event itself as a "profession" or livelihoods day, by doing a sexual relationship. ${ }^{5}$

In Cirebon itself particularly in jurisdictions Police Resort Cirebon online prostitution criminal action has not handled many such cases, because the inquiry and technological factors that have not been adequate, but the Polres Cirebon investigators continue to improve the investigation of this criminal act. ${ }^{6}$ Because the incidence of crime generally consist of two parts, namely, the internal factor is the factor causes of the man himself without environmental influences such as the level of emotional, psychiatric disorders, personality, sex, position in the family. While external factors are the cause of external factors such as pressure perpetrator economic, environmental and others. ${ }^{7}$ If prostitution is done in the online world it can be subject to Article 27 paragraph (1) Act No. 11 Of 2008 on Information and Electronic Transactions reads: "Any person intentionally and without right of distribution and / or transmition and / or create can access electronic information and / or electronic documents that have a charge of violating decency in crime with imprisonment of 6 (six) years and / or a fine of not more Rp. 1.000.000.000, - "

In this case shows how a case such as prostitution has become a sociological problem in society which in this case is contrary to Pancasila that upholds the norms and customs value. $^{8}$

And when the act of prostitution was contagious and detrimental to the public in this country either materially above such actions give legal sanction, but the rule of law against the perpetrators of acts of prostitution does not exist, then the prostitutes can not be given legal sanctions described in the legislation. ${ }^{9}$

In other words, here the people in charge to be able to respect the norms and values contained in the lives of the people in because cases of online prostitution can destroy the future of the nation as their cases were found with the offender who was aged teenager and is still a lack of traction regulation to entrap prostitutes.

\section{Research methods}

In view of the corner of the methods used, this research is a sociological study. Legal research sociological research may be about to see the correlation between law and society. Because in this study the authors directly conduct research on the location or place in carefully in order to provide complete and clear picture of the issues examined. Thus, expect able menggungkapkan effectiveness of the rule of law in society and be able to

\footnotetext{
${ }^{4}$ E-journal.uajy.ac.id/7206/1/jurnal.pdf.

${ }^{5}$ http://skripsi-konsultasi.blogspot.com/2012/12/judul-skripsi-psikologisosiologi.html.

${ }^{6}$ Interview with Indrawati SH Chief of Cirebon Police Resort City Unit

7Erdiansyah " Menjerat Pelaku Tindak Pidana Prostitusi secara Online," the witness.

${ }^{8}$ Soerjono Soekanto 2007 Faktor-Faktor Yang Mempengaruhi Penegakan Hukum PT. Raja Grafindo Persada Jakarta.

${ }^{9}$ http://skripsi-kosultasi.blogspot.com/2012/12/judul-skripsi-psikologisosiologi.html Accessed on October 22 2015.
} 
identify the unwritten law in force in the community. ${ }^{10}$

\section{Results And Discussion}

\subsection{Law Enforcement On Online Prostitution A Criminal Offense In The Polres Cirebon City Jurisdiction}

According Soerdjono Soekanto, rule of law is to harmonize their activities relations values that span the 'hierarchy in the rule steady and attitude acts as a series of translation of the value of the final stage, to create, maintain and sustain peace of social life. ${ }^{11}$

Based on interviews with the Iptu Indrawati, SH. as investigators of women and children in Polres Cirebon that problems associated with online prostitution was never there and have done a series of law enforcement, ranging from investigation to investigation. ${ }^{12}$ From the results of the investigation conducted by the Police Department in the Polres Cirebon know that criminals take advantage of online prostitution through whatsapp. Customers can trade or hire a woman in the show in a social network page without the name. In the case of online prostitution in the jurisdiction of the Polres Cirebon investigators mostly just received a report from the community. Because of the limitations of which are owned by the investigator in terms of technology is therefore in this case the investigator to perform an action with surveillance, and disguises. Investigators will come into place in the set and arresting suspects. ${ }^{13}$

Law created by the authorities as a system power control human behavior. As it is binding norms for each individual to obey and follow all the rules contained therein. The existence of cyber law, in this context applies for the netters who interact in cyber space. In order for the law to work it must qualify as the legal validity of the rules are: ${ }^{14}$

- The rule of law applies legally, if the determination is based on the rules of the higher level or are formed on the basis of which has been set;

- The rule of law applies in sociological, if the rule is effective. That is, the rule can be enforceable by the authorities, although not accepted by the community (theory of power) or the rules that apply for their recognition of the community;

- The rule of law applies philosophically, that is in accordance to the law as the highest positive value.

Prostitution is a form of sexual crimes committed with or without violence. This is done by violent crime if prostutisi do with trafficking and coercion. Cases of sexual trafficking of children under the age of the woman shows that the reality of women's rights to enjoy the peace and happiness were broken at an early age (underage). Right to live in dignity and free from the danger he had been in the reduction of the crime.

Sexual crime not only affects women, but also afflicts children "minors". The girl made the object of a commodity (trading) or gratification in debauched (animalistic) of a person and a particular group of sexual conduct business in order to achieve economic benefits multiply. ${ }^{15}$

With internet media they have several advantages, for example, the average customer -

\footnotetext{
${ }^{10}$ Soerjono Soekanto op.cit p.25.

${ }^{11}$ Soerjono Soekanto op.cit

${ }^{12}$ Results Interview with Indrawati SH. as the investigator at Polres Cirebon

${ }^{13}$ Adami Chazwi 2015 Ardi Ferdian Tindak Pidana Informasi dan Transaksi Elektronik Media Nusa Creative.

${ }^{14}$ Zainudin Ali 2010 Fisafat Hukum Sinar Grafika: Jakarta.

${ }^{15}$ Ibid.
} 
well educated. In addition, if the prospect is not pleasing, sex workers do not need to spend time or expend the cost to come to the prospective customers. Meanwhile, for the customer is quite advantageous considering the sex worker is already detailing the data themselves. Dealing with sex workers who volunteered through online media is also considered more convenient. What's more, most of the sex workers come from the lower middle class. ${ }^{16}$

\subsection{Barriers In Law Enforcement Online Prostitution Criminal Offenses In The Polres Cirebon City Jurisdiction}

Obstacles in online law enforcement in the Police Cirebon jurisdiction is as follows:

- Legal awareness is not optimal

One obstacle in law enforcement criminal acts of online prostitution is the lack of public awareness on the implications for their disobedience to the law. M. Arif Mansur and Ekisatris Gultom formulate some reason then until now Indonesian legal awareness is still lacking, namely: Until now, the Indonesian public legal awareness in responding to cyber crime activities is still lacking. This is caused partly by a lack of understanding and knowledge of the community to this type of cyber crime. ${ }^{17}$

- There are limitations in facilities and infrastructure

According to interviews conducted by the author to thelptu Indrawati, SH. he said that one of the obstacles to law enforcement in criminal activities online prostitution is the lack of infrastructure which is owned by the Polres Cirebon, because the crime is done online then there are things that only technically owned by the National Police Headquarter. ${ }^{18}$ For example as in the form of a tools tracking phone number or a tool taping / recording via mobile phone either chat or telephone.

- Very few cases that until the trial

Cyber crime law enforcement, especially the crime of online prostitution is also still encounter obstacles so that the crimes has been investigated by the police are very few who come to the trial. This is caused partly because not enough evidence at present in each set of examinations.

The police are also difficult to carry out the investigation process to determine which victims are really caught by deceit pimps, and which are voluntary to join in a prostitution ring, because not all the girls are victims netting prostitution business, sometimes their own decided to participate in the prostitution ring, so that if they are caught they are as - if the victim. While investigators could only apply $A$ lesson to pimp sexs temporary workers and users no punishment.

\subsection{Efforts To Overcome Obstacles In The Enforcement Of Criminal Acts Of Online Prostitution In Polres Cirebon City Jurisdiction}

To optimize law enforcement against criminal acts of online prostitution at least can be analyzed from the opinion of Judge Stenin Schjolberg and Amanda M. Hubbard where they put forward in the cyber crime problem is in need of standardization and harmonization in three areas, namely legislation, criminal enforcement and judicial review. This shows that the issue of harmonization is a problem that is not stopped by in undangkannya laws

\footnotetext{
${ }^{16}$ http: //indosiar.com-hitamputihpornografi-diduniamaya On 5 April 2016

${ }^{17}$ Ibid.

${ }^{18}$ Results Interview with Inspector Indrawati SH. as the investigator at the Polres Cirebon
} 
governing cyber crime, much of it is the cooperation and harmonization in the law enforcement and judicial. ${ }^{19}$

Efforts are being made to overcome the barriers in law enforcement against online prostitution a criminal offense in the jurisdiction of the Polres Cirebon are as follows:

- Build partnership with the community at large

Based on interviews with Iptu Indrawati, SH. As part of the Protection of Women and Children., Efforts will be undertaken Police Cirebon Urban in overcoming hambayan those found in the enforcement of laws against the crime of online prostitution among others by building partnerships in the wider community to help hack into your account an account associated with women through online media.$^{20}$

- Improve infrastructure and facilities

Other attempts to overcome the barriers in law enforcement in criminal acts of prostitution undertaken Polres Cirebon is to improve the facilities and amenities.

In the absence of facilities for certain, it is unlikely that law enforcement will take place has gone well. Facilities and infrastructure, among other things covers manpower educated and skilled, good organizations, adequate equipment, adequate financing and so on.

\section{Closing}

\subsection{Conclusion}

Based on the description that has been the author convey in writing the manuscript describing and analyzing the elements of online prostitution crimes, sanctions and criteria in the discussion of this study, it can be concluded as follows:

- Online prostitution may occur because of the easy access and also so free, existence of a website or forum that is specially engaged in the world of online prostitution further confirms that this illicit practice has been very well organized. They usually visit the forums or the website, in it have a special room to discuss about this event, we just choose the girl - a girl in it clearly defined as to what this prostitute girls ranging from tariffs to the body shape. After agreeing live call by telephone pimps and prostitution through online media ensued. Factors causes of prostitution through online media is basically the same as how prostitution is common, usually utaman factor is the economy,

- Positive law responding to problems of prostitution through online media is quite satisfactory for the community, although there are still gaps in it. Using three of Indonesian Law, Act No.11 of 2008 on Information and Electronic Transactions, Legal Indonesia Act 44 of 2009 on Pornography and the Criminal Code was enough to catch the culprit, but there are loopholes in it as if the server and the owner website or forum prostitution is not a citizen of Indonesia, then he can just escape the law of Indonesia. Online prostitution crime in Islamic law it can be likened to a crime that threatens damage qurbuzzina fifth pillar of Maqasid Al Shari'ah. The criteria for online prostitution by criminal law of Islam is: subjects or actors mukallaf.

\footnotetext{
${ }^{19}$ Judge Stenin Schjolberg dan amanda M. Hubbard 2005 Harmonizing National Legal Approaches on Cyber Crime WSIS Thematic Meeting on Cybersecurity Geneva p 28.

${ }^{20}$ Results of interviews with Iptu Indrawati SH As part of the Protection of Women and Children in Polres Cirebon
} 
- Criminal sanctions for online prostitution in the Islamic law with penalties that can be either prison ta'zir (al-Habsu) or fines except for pimps, prostitutes and user services set out in the Qur'an. Penalties for perpetrators of online prostitution regulated in ICT Act and Pornography Act is still less severe according to the author, for a maximum fine of Rp. 1 billion is still relatively small compared to the advantages to be gained in managing this online prostitution ring. While the imprisonment of a maximum of 6 years is still considered mild when considering prostitution more dangerous than other forms of pornography, making it less effective to create a deterrent or scare actors people doing similar crimes.

\subsection{Suggestion}

- Penalties for online prostitution have been stipulated in the Law on Information and Electronic Transactions and the pornography law, should include more explicit sentence boundary, ie, with specified minimum limit of imprisonment or a fine. Because the articles of the penal provision only includes the phrase sentence "maximum" or "longest" to imprisonment, and "most" of fines. This is the opposite of prostitution as a form of crime that are considered more dangerous, disturbing the public and wider negative impact than other kinds of pornography, and to avoid the provision of criminal sanctions is relatively low.

- Crime online prostitution is a crime-based hi-tech, for it required the officers executing that also has expertise in the field of information technology supported by means of a sophisticated Similarly, in order to track criminals and anyone who is involved in making a website or forum and the owner of the server.

- Needs to be done treaty - extradition treaties with other countries, considering this crime are transborder or cross-region, as in the previous discussion is said to be the server owner may open the Indonesian nationality. In other words the necessary cooperation with the country where server owners who allow and facilitate the practice of prostitution.

\section{Bibliography}

[1] Ali Zainudin 2010 Fisafat Hukum Sinar Grafika: Jakarta.

[2] Cahyana Ahmadjayadi 2007 "Cybercrime And Cyberporn Associated With Electronic Information And Transaction Bill" On BPHN convey to the seminar by the Ministry of Justice.

[3] Erdiansyah 2015 " Menjerat Pelaku Tindak Pidana Prostitusi secara Online," a witness

[4] Hazwi Adami Ardi Ferdian 2015 Crime and Transaction Information Electronic Medical Nusa Creative.

[5] http://Ejournal.uajy.ac.id/7206/1/jurnal.pdf

[6] http://indosiar.com-hitamputihpornografi-diduniamaya

[7] Interview with Indrawati SH Chief of Police Cirebon Resort City Unit

[8] Soekanto Soerjono 2007 Faktor - faktor Yang Mempengaruhi Penegakan Hukum PT. Raja Grafindo Persada Jakarta.

[9] Stenin Judge Schjolberg M. Hubbard Amanda 2005 Harmonizing NationalLegal Approaches on Cyber Crime WSIS Thematic Meeting onCybersecurity Geneva.

[10] Terence H Hull Endang Sulistianingsih Gavin W.J 1997 Pelacuran di Indonesia Jakarta: Pustaka Sinar Harapan. 